\title{
CHROMOSOME NUMBERS OF SOUTH AFRICAN GRASSES
}

\author{
By A. A. MOFFETT \\ Wattle Research Institute, University of Natal \\ and \\ R. HURCOMBE \\ John Innes Horticultural Institution, Bayfordbury
}

THE following list of chromosome numbers is a combination of the studies of Dr Moffett on grasses of Rhodesia and Miss Hurcombe on grasses of the provinces of the Union of South Africa. Dr Moffett's species were identified by Miss K. Sturgeon of the Department of Agriculture, Salisbury, Southern Rhodesia ; Miss Hurcombe's species were grown from seed supplied by Miss Wilman through the Director, Royal Botanic Gardens, Kew, or roots were sent directly from South Africa, and specimens of these have been preserved in the Kew Herbarium (Editor).

Notes after the numbers refer to comparison with previous counts given in the Chromosome Atlas where the full references to the original papers will be found.

TRIBE II-ANDROPOGONEA

\begin{tabular}{|c|c|c|c|}
\hline \multirow[t]{14}{*}{$x=\mathrm{IO}$} & $\begin{array}{l}\text { ROTTBOELLIA } \\
\text { exaltata L.f. } \\
\text { SORGHUM }\end{array}$ & . 20 & S. Rhodesia \\
\hline & sudanense (Piper) Stapf . & 20 & , \\
\hline & $\begin{array}{l}\text { friesii (Pilger) C. E. Hubbard } \\
\text { (micratherum Stapf) }\end{array}$ & $4^{\circ}$ & " \\
\hline & $\begin{array}{l}\text { SCHIZACHYRIUM } \\
\text { glabrescens (Rendle) Stapf }\end{array}$ & & \\
\hline & $\begin{array}{l}\text { jeffreysii (Hack.) Stapf . } \\
\text { DIECTOMIS }\end{array}$ & $\cdot 40$ & ", \\
\hline & $\begin{array}{l}\text { fastigiata (Swartz) Kunth } \\
\text { ANDROPOGON }\end{array}$ & 20 & , \\
\hline & eucomus Nees & . 20 & , \\
\hline & schirensis Hochst. ex A. Rich . & - 40 & ", \\
\hline & amplectens Nees . & $\cdot 40$ & ", \\
\hline & schinzii Hack . . & - 40 & ," \\
\hline & $\begin{array}{l}\text { gayanus Kunth var. squamulatus } \\
\text { (Hochst.) Stapf } \\
\text { HYPARRHENIA }\end{array}$ & s 40 & " \\
\hline & $\begin{array}{l}\text { dissoluta (Nees ex Steud.) C. E. } \\
\text { Hubbard (ruprechtii Fourn.) }\end{array}$ & 40 & " \\
\hline & $\begin{array}{l}\text { newtonii (Hack.) Stapf } \\
\text { MONOCYMBIUM }\end{array}$ & 40 & "? \\
\hline & ceresiiforme (Nees) Stapf & 20 & ", \\
\hline
\end{tabular}


$x=\mathrm{II}$ HETEROPOGON

melanocarpus (Ell.) Benth.

. 22

S. Rhodesia

contortus (L.) Beauv. ex R. \& S. 44 (not 20)

,

TRIBE III.-PANICE EE

$x=7,9 \quad$ UROCHLOA

pullulans Stapf . . . 28

mosambicensis (Hack.) Dandy 42

$(=\mathrm{U}$. pullulans var. mosam-

bicensis Stapf)

bolbodes (Schweinf.) Stapf . 36

$x=8,10,11$ PANICUM

panicoides Beauv. (helopus Stapf) 36

maximum Jacq. . . . $32($ not 36$)$

Dwarf type and green mutant 32

vars. Red Buffel, Coarse Guinea, 32

Fine Guinea

two vars. Puerto Rico . . 32

"makarikari" . . . . 44

$x=9$

DIGITARIA

milanjiana (Rendle) Stapf . 18

brazze (Franch.) Stapf . . 18

gazensis Rendle . . $\quad{ }_{18} 8$

$\begin{array}{llll}\text { eriantha } \text { Steud. } & \text {. } & \text {. } & 18\end{array}$

pentzii Stent . . . 54

swazilandensis Stent $\quad . \quad .18$

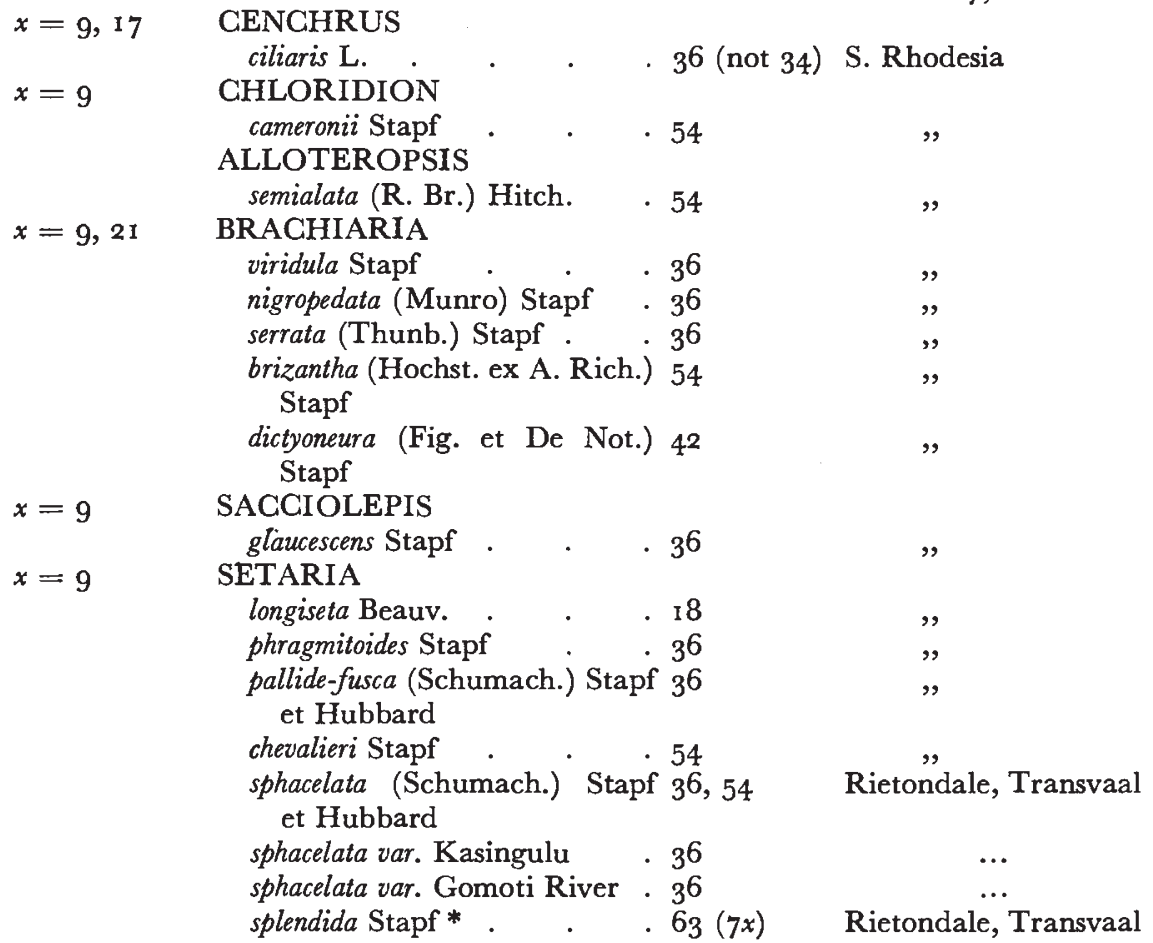

* Setaria splendida -a tall vigorous grass which does not set viable seed-proved to be heptaloid. 


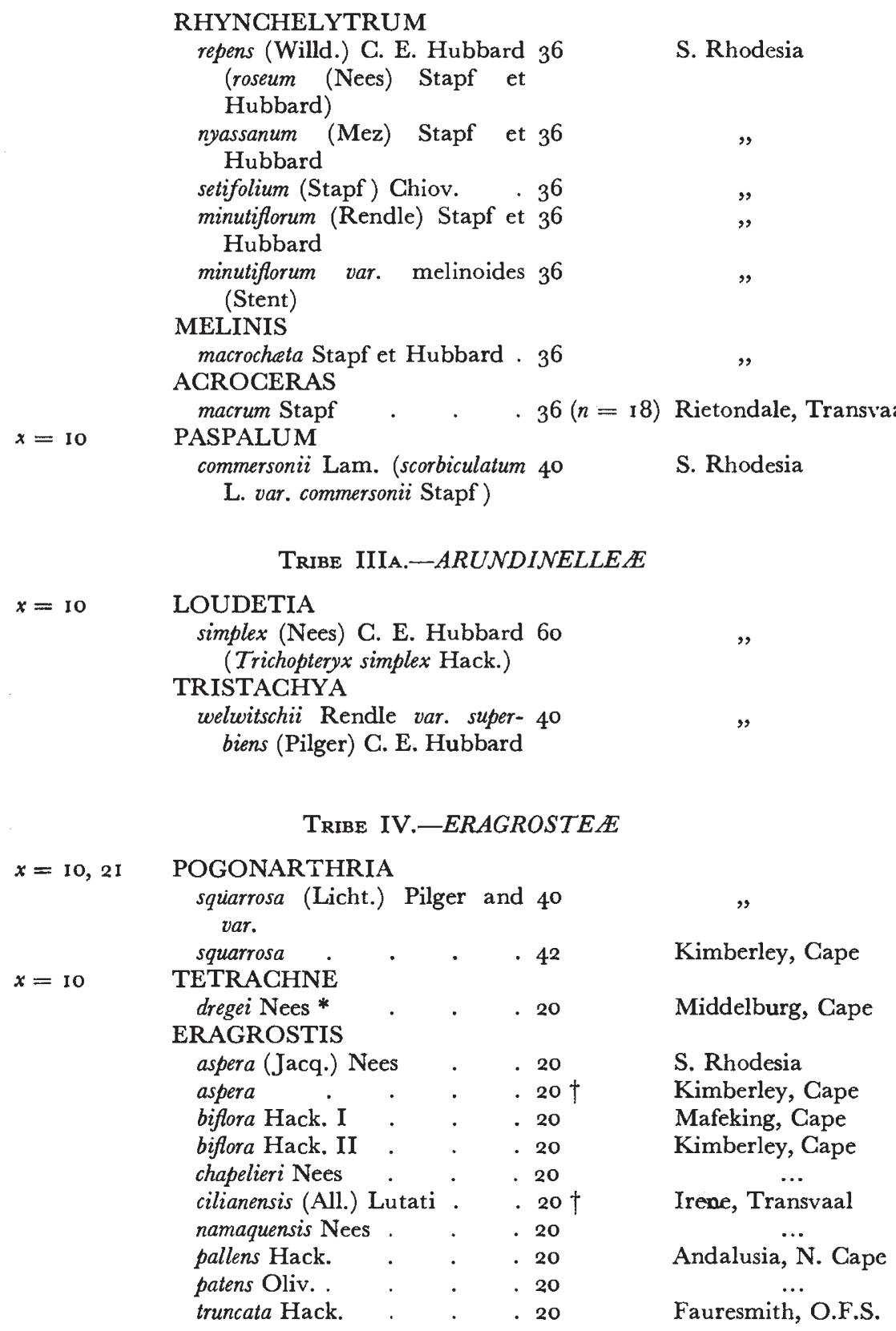

* Tetrachne is a monotypic genus which has not previously been studied. Stapf (Flora Capensis, 7, 318, 1898) places this genus in the tribe Festuceæ. The somatic chromosomes of true members of the Festucea, e.g. Festuca, Poa and Dactylis are twice as long as those of $T$, dregei. Also, the majority of the Festuceæ have a basic number of 7 whereas the count for $T$. dregei indicates a basic number of 1o. Mr C. E. Hubbard has found that this grass differs from the genera of the tribe Festuceæ and from allied tribes of the festucoid group in certain morphological and anatornical features. The morphological, anatomical and cytological evidence both indicate that Tetrachne should be removed from the Festucex. For the present the genus might be conveniently included in the Eragrosteæ.

$\dagger$ Confirming Avdulov I93. 
$x=10$

(10)

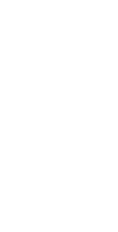

$x=9$, го

$x=10$

$x=9$, 10

\section{ERAGROSTIS-continued}

wilmanie Hubb. et Schw.

20

atherstonei Stapf I .

atherstonei Stapf II

ciliaris (L.) R. Br.

denudata Hack.

echinochloidea Stapf

margaritacea (?)

obtusa Munro

sclerantha Nees (small type) . $4^{\circ}$

sclerantha Nees (large type) . 40

superba Peyr.

tef (Zucc.) Trotter (E. abys- 40 sinica Link)

viscosa (Retz.) Trin. . . 40

barrelieri Daveau . . . 60

capensis Trin. (brizoides Nees) . 60

habrantha Rendle.
- 40

- 40

- 40

- $4^{\circ}$

- 40

40

40 40 40 40

6 o, $90(6 x$ and $9 x$ )

\section{TRIBE V. $\longrightarrow S P O R O B O L E A E$}

\section{SPOROBOLUS}

fimbriatus Nees panicoides A. Rich.

. 18

- 24

pyramidalis Beauv.

. 24

pyramidalis .

. $30\left(3^{x}\right)$

capensis (Willd.) Kunth

. 36

Hay Division, Griqualand West

Mafeking, Cape

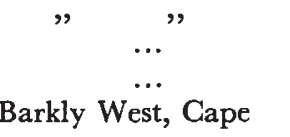

Kimberley, Cape

S. Rhodesia

Kimberley, Cape

S. Rhodesia

Kimberley, Cape

S. Rhodesia

Tribe VI.-ZOISIEAE

\section{PEROTIS}

patens Gand.

$\cdot 40$

S. Rhodesia

Kimberley, Cape

S. Rhodesia

Irene, Transvaal

S. Rhodesia

TRIBE VII.-CHLORIDEAE

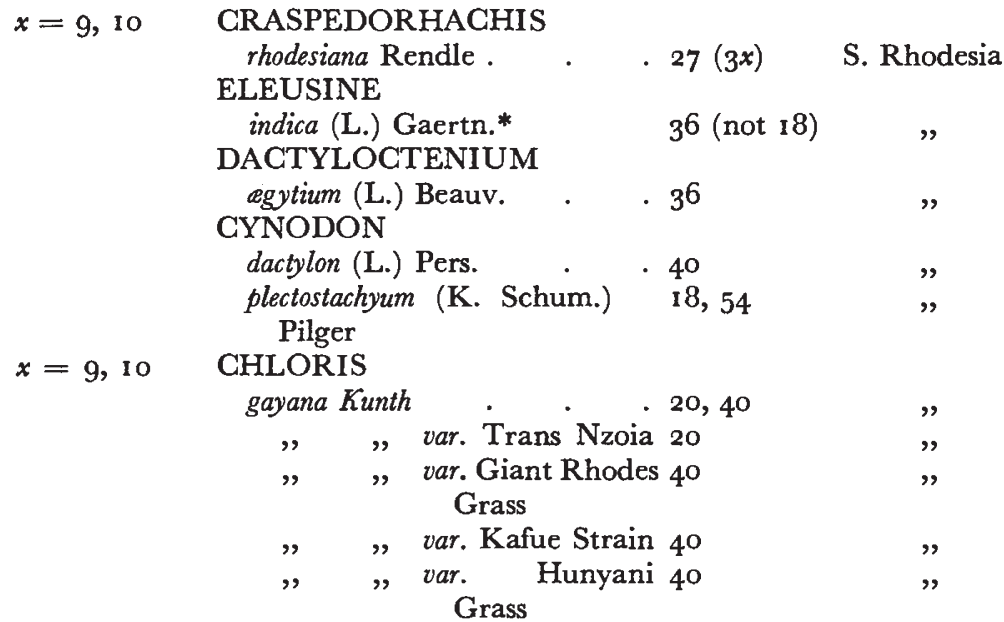

* Eleusine indica $2 n=36$ and not $2 n=18$. This may be tetraploid strain. It is generally considered that this species becomes larger and more aggressive as one proceeds north from S. Africa. It is certainly much more formidable in Rhodesia than in Natal, but this may be due to climate and soil as much as to any inherent differences. 
$x=9$, Io CHLORIS-continued

virgata Swartz * . . . 20 (not I4) Mafeking, Cape

pycnothrix Trin. . . . . 40 Irene, Transvaal

MICROCHLOA

Kunthii Desv. . . . $40 \quad$ S. Rhodesia

TRICHONEURA

grandiglumis (Rendle) Ekman 20 "

TRIBE IX.-ARISTIDEAE

$x=\mathrm{I} \mathrm{I}$

ARISTIDA

meridionalis Henrard . . 22

scabrivalvis Hack. . . . 22

S. Rhodesia

macilenta Henrard (contractinodis 22

,

Stent et Rattray)

congesta Roem. et Schult. . 22

scabrivalvis (?) . . . . 22

leucophea Henrard . . 44

,

,

,

,

* Nielsen and Humphrey (1937) counted 14 chromosomes in Chloris virgata. The present revised count of $2 n=20$ agrees with previous counts of other species of Chloris.

N.B.-The manuscripts have been arranged and edited by Mr C. E. Hubbard of the Royal Botanic Gardens, Kew, and Dr G. D. Darlington.

\section{REFERENCES}

DARLINGTON, C. D., AND JANAKI AMMAL, E. K. 1945.

Chromosome Atlas of Cultivated Plants. London : Allen \& Unwin. 